九州大学学術情報リポジトリ

Kyushu University Institutional Repository

\title{
Water Requirement Analysis of Paddy Field Irrigation System in Diversified Land Use Area
}

Basri, Hairul

Laboratory of Irrigation and Water Utilization Engineering, Faculty of Agriculture, Kyushu University

Nakano, Yoshisuke

Laboratory of Irrigation and Water Utilization Engineering, Faculty of Agriculture, Kyushu University

\section{Kuroda, Masaharu}

Laboratory of Irrigation and Water Utilization Engineering, Faculty of Agriculture, Kyushu University

\section{Fukuda, Tetsuro}

Laboratory of Irrigation and Water Utilization Engineering, Faculty of Agriculture, Kyushu University

他

https://doi.org/10.5109/24319

出版情報：九州大学大学院農学研究院紀要. 44 (1/2)，pp. 175-187，1999-11. Kyushu University バージョン：

権利関係 : 


\title{
Water Requirement Analysis of Paddy Field Irrigation System in Diversified Land Use Area
}

\author{
Hairul Basri, Yoshisuke Nakano, Masaharu Kuroda, \\ Tetsuro Fukuda and Tamotsu Funakoshi
}

\author{
Laboratory of Irrigation and Water Ctilization Engineering, Faculty of Agriculture, Kyushu \\ University, Hakozaki, Higashi--ku, Fukuoka 812-8581, JAPAN \\ (Received July 25, 1999 and accepted August 24, 1999)
}

\begin{abstract}
The study aimed to investigate the characteristics of net water requirement and the gross water requirement of paddy lield irrigation in diversified land use area. The net water requirement, which is the net quantity of water demanded in paddy plot, is clarificd using the tank model. The tank model consisted of 6 sub tank i.e., irrigation canal tank, paddy tank, upland tank, settlement, tank, greenhouse tank and drainage canal tank. The main purpose of using the tank model is to find out the acceptable values of outflow from each sub tank model. Results based on 4 years historical clata depicted that the paddy fields yielded the dominant discharge compared to other land use type. The quantity of net water requirement of paddy fields was obtained using the acceptable of the tank model. Furthermore, the deep percolation and surface runoff from paddy fields were the dominant component of the net water requirement.

The acceptable of the tank model was applied for predicting the gross water requirement. Intake water from Yamada weir of 1998 named as observed gross water requirement was used for simulating the gross water requirement. Results showed that the observed gross water was slightly higher than the simulated gross water requirement. The simulated gross water requirement recommended as reference for deciding the gross water requirement in this area because of its efficiency. And the reasonable of simulated ponding depth also supported the result. Furthermore, the results of numerical treatment of gross water requirement showed that the application of the gross water requirement of $5 \mathrm{~m}^{3 /} / \mathrm{s}$ was reasonable compared to other treatment.
\end{abstract}

\section{INTRODUCTION}

It is well known that there are two kinds of water requirement i.e., (1) net water requirement, and (2) gross water requirement. Net water requirement is the net quantity of water demanded in paddy plot. And gross water requirement shows the water quantity which should be diverted at diversion point each irrigation scheme (Mizutani, 1991). Amount of irrigation water given to paddy crops is one of the most essential things that has to be analyze not only for providing crop need to sustained high yield but also for reducing management loss of water operation in the system (Basri et al. 1998).

Increasing area of upland crops that was converted from paddy area caused the decreasing of paddy area. Usually, the decrcasing of paddy area influenced the irrigation water supplied into paddy field system. However, it seemed that there was no significant changing of gross water requirement in spite of decreasing the paddy area in irrigation scheme in this area, which was operated under traditional water right. This phenomenon means that application of gross water requirement operated under traditional water right in this area did not be adjusted with real condition of water requirement in the fields. On 
the other word, irrigation water supplied to paddy field system some times was higher than the real water requirement.

Besides the conditions of soil properties and climate, the water requirements are strongly influenced by field management and canal management, which means that the knowledge of farmers in managing the paddy fields has to be considered as an important thing. Therefore, it is important to reevaluate the real condition of water requirement for increasing the high efficiency of water management in this area.

This study aimed to investigate the characteristics of the net water requirement in paddy plot and the gross water requirement that is done by clarifying the water balance phenomena in a plot paddy field system. The water balance is clarified using a logical tank model. The main purpose of using the tank model is to find out the acceptable values of out flow from each sub tank model. Historical 4 years of observation discharge data (1979-1982) in a plot paddy model were used for simulating water cyclic in the area using the tank model. The performance of simulated discharge and the quantity of net water requirement were obtained. The acceptable of tank model was used for predicting the gross water requirement in the area. In this case, the intake water from Yamada weir of 1998 was taken as the input parameter to the area. Furthermore, numerical treatment of gross water requirement was also discussed for finding the reasonable of operation and water management in this area.

\section{DESCRIPTION OF STUDY AREA}

The research was carried out as a case study of paddy irrigation system in diversified land use area in Asakura Town, Fukuoka Prefecture, Kyushu, Japan as shown in Fig. 1. The area is flat. The yearly average temperature is $16^{\circ} \mathrm{C}$ and the annual rainfall is approximately $1800 \mathrm{~mm}$. The soil condition is porous and has low ground water table. Fig. 1 show the schematic representation of study area in paddy plot model. Irrigation water for the paddy fields system is taken from Yamada Weir delivering into irrigation canal using open channel system.

Typical of water circulation in the area is presented in Fig. 2. Paddy field system consists of 6 sub system i.e., irrigation canal, paddy fields, greenhouses, upland fields, settlement areas and drainage canal. Inflow from irrigation canal onto paddy field system is done for fulfilling the water demand of paddy fields and upland fields. Meanwhile, the water demand of greenhouses is taken from ground water. Deep percolation from paddy fields, greenhouses and upland fields are considered as water loss from the system. On the contrary, outflow from each component of paddy field system due to seepage and surface flow is appeared in drainage canal. Furthermore, the total of observed inflow and outflow of irrigation canal and drainage canal in Fig. 1 were used for simulating the water cyclic in the system. Based on this typical of water circulation, a complex tank model for simulating water cyclic in the system was constructed as presented in Fig. 3.

Furthermore, physical data of surveyed area is shown in Table 1. Generally, it present that paddy fields occupy the dominant area compared to other types of land use. The increasing of upland area causes the decreasing of paddy area. 


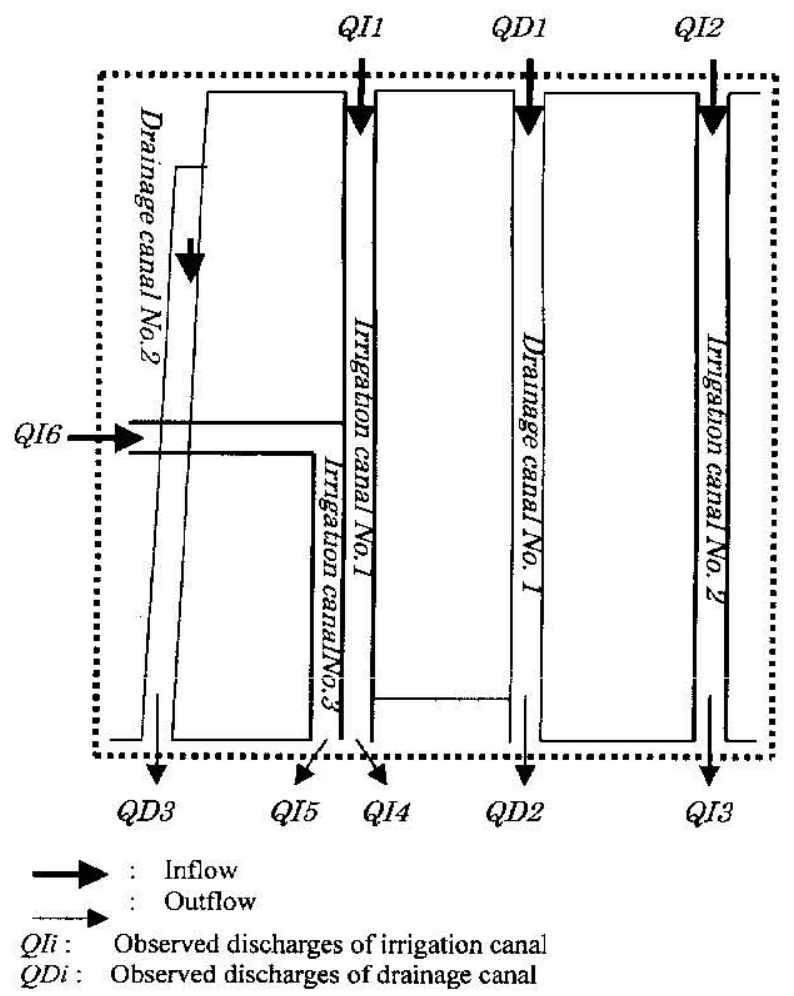

Fig. 1. Schematic representation of study area in Ásakura Town, Fukuoka Prefecture, Japarl.

Table 1. Physical data of surveyed area.

\begin{tabular}{cccccc}
\hline Year & $\begin{array}{c}\text { Paddy fields } \\
\text { (ha) }\end{array}$ & $\begin{array}{c}\text { Upland fields } \\
\text { (ha) }\end{array}$ & $\begin{array}{c}\text { Greenhouses } \\
\text { (ha) }\end{array}$ & $\begin{array}{c}\text { Settlement areas } \\
\text { (ha) }\end{array}$ & $\begin{array}{c}\text { Total } \\
\text { (ha) }\end{array}$ \\
\hline 1979 & 10.66 & 0.44 & 2.66 & 1 & 14.76 \\
1980 & 10.00 & 1.10 & 2.66 & 1 & 14.76 \\
1981 & 8.48 & 2.62 & 2.66 & 1 & 14.76 \\
1982 & 8.52 & 2.28 & 2.96 & 1 & 14.76 \\
\hline
\end{tabular}



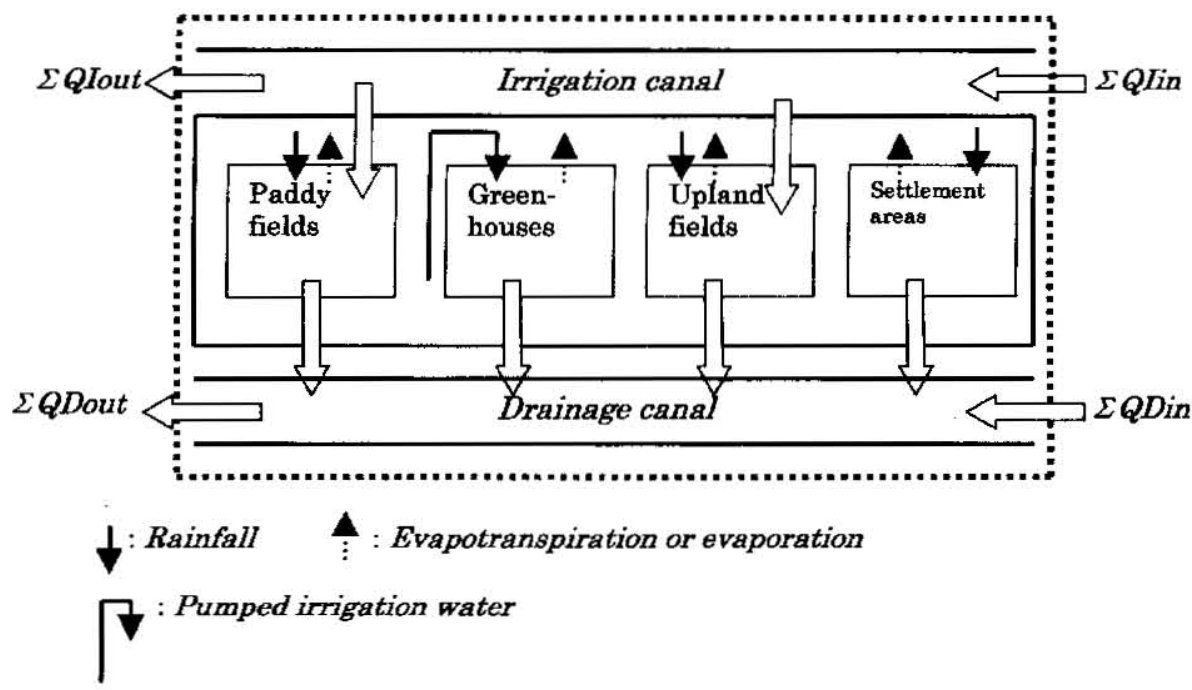

EQrin, EQioui: Total infiow and ouiflow discharges through irrigation canal, respectively $\Sigma$ QDin, $\Sigma$ QDout : Total inflow and outflow discharges through drainage canal, respectively.

Fig. 2. Typical water circulation in the paddy field system.

\section{MODEL APPROACH}

There were three main works of analysis have been carried out for clarifying the water requirement phenomena. First is to make clearly the water balance and concerning component using a Tank Model for simulating the water cyclic in the plot model. Observed 4 years of historical discharge data (Kuroda, 1985) had been used for simulation. Furthermore, the performance of simulated discharge and the net water requirement are obtained. Second is to use the acceptable of Tank Model for predicting the gross water requirement. In this case, intake water from Yamada weir of 1998 that was known as the observed water requirement had been used as input water for simulating the gross water requirement. Last is to carry out the numerical treatment of gross water requirement that is also conducted using the acceptable tank model for finding the reasonable of operation and water management in this area.

\section{Water Balance in the System}

The water balance in the paddy irrigation system was analyzed using a complex tank model as shown in Fig. 3. The tank model was consisted of 6 sub tank model i.e., the irrigation canal tank, the paddy tank, the upland tank, the settlement tank, the greenhouse tank and the drainage canal tank. From Fig. 3, the water balance is expressed as follows.

Irrigation canal tank

$$
X i c_{j}=X i c_{y-1}+\text { Qinic }_{j}+\text { Ric }_{j 3}-\text { Qinpd }_{j}-\text { Qinup }_{i}-\text { Eic }_{j}-\text { Qoutic }_{j}
$$


Paddy tank:

$$
X p d_{j}=X p d_{j}+Q i n p d_{j}+R p d_{s}-D P p d_{j}-E v t p d_{j}-Q o u t p d_{j}
$$

Upland tank:

$$
X u p_{j}=X u p_{j}+\text { Qinup }_{3}+\text { Rup }_{j}-\text { DPup }_{j}-\text { Evtup }_{j}-\text { Qoutup }_{j}
$$

Settlement tank :

$$
X s t_{j}=X s t_{j}+R s t_{j}-E s t_{j}-\text { Qoutst }_{j}
$$

Greenhouse tank :

$$
X g h_{1}=X g h_{j^{-1}}+P g h_{j}+R g h_{j}-D P g h_{j}-E v t g h_{h_{j}}-Q o u t g h_{j}
$$

Drainage tank :

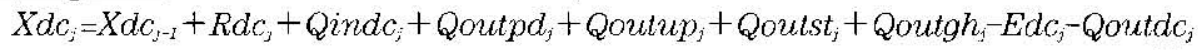

Where, $j$ is present period; $X i c_{j}, X p d, X u p_{j}, X s t_{j}, X g h_{j}$ and $X d c_{j}$ are height of water storage in irrigation canal, paddy fields, upland fields, settlement areas, greenhouses and drainage canal at period $j$, respectively; $X i_{j-1}, X p d_{j_{-1}}, X u p_{j-1}, X s t_{j 1}, X g h_{j-1}$ and $X d c_{j-1}$ are height of water storage in irrigation canal, paddy fields, upland fields, settlement areas, greenhouses and drainage canal at period $j-1$, respectively; $R i c_{j}, R p d_{j}, R u p_{j}, R s t_{j}, R g h_{j}$ and $R d c_{j}$ are rainfall into irrigation canal, paddy fields, upland fields, settlement areas, greenhouses and drainage canal at period $j$, respectively; Qinic, Qinpd $_{j}$, Qinup and $_{j}$ Qind $c_{j}$ are inflow into irrigation canal, paddy fields, upland fields and drainage canal at perjod $j$, respectively; $D P p d_{j}, D P u p_{j}$ and $D P g h_{j}$ are deep percolation in paddy fields, upland fields and greenhouses at period $j$, respectively; $P g h_{j}$ is pumped water originated from ground water into greenhouses at period $j ; E i c_{j}, E s t_{j}$ and $E d c_{j}$ are evaporation from irrigation canal, settlement areas and drainage canal at period $j$, respectively. $E v t p d_{j}$, $E_{v t u p_{j}}$ and Evtgh, are evapotranspiration from paddy fields, upland area and greenhouses at period $j$, respectively. Qoutic $c_{j}$, Qoutpd $d_{j}$, Qoutup ${ }_{j}$, Qoutst, Qoutgh, and Qoutdc $c_{j}$ are outflow from irrigation canal, paddy fields, upland fields, settlement areas, greenhouses and drainage canal at period $j$, respectively;

\section{Construction of Tank Model for Analysis}

As presented in Fig. 3, first, the terms of rainfall and infilow into drainage canal were input parameters for the irrigation canal tank. The evaporation, the outflow from drainage canal to out of system and the outflow both into paddy fields and into upland fields were considered as the output parameters for the irrigation canal tank. Much of water was supplied into paddy fields and other was used supplementary for upland fields. Second, the terms of rainfall and inflow from irrigation canal into paddy fields were treated as the input parameters for the paddy tank. The deep percolation and the water flows from paddy fields into drainage canal and the evapotranpiration from paddy fields were dealt as the output parameters for the paddy tank. Third, the terms of rainfall and inflow from irrigation canal into upland fields were considered as the input parameters for the upland tank. The deep percolation and the water flows from upland fields into drainage canal and the evapotranspiration from upland fields were dealt as the output parameters for the upland tank. Fourth, the term of rainfall into settlement areas was treated as the input parameters for the settlement tank. The outflow from settlement areas into drainage canal and the evaporation from settlement areas were dealt as the output parameters for the settlement tank. Fifth, the terms of pumped water from 
ground water into greenhouses was treated as the input parameters for the greenhouse tank. The outflow from greenhouses into drainage canal and the evaporation from greenhouses were dealt as the output parameters for the greenhouse tank. Finally, the terms of rainfall, inflow from the upper block and outflow from paddy fields, upland fields, settlement areas and greenhouses into drainage canal were treated as the input parameters for the drainage canal tank. The evaporation and the outflow from drainage canal were treated as the output parameters for the drainage tank.

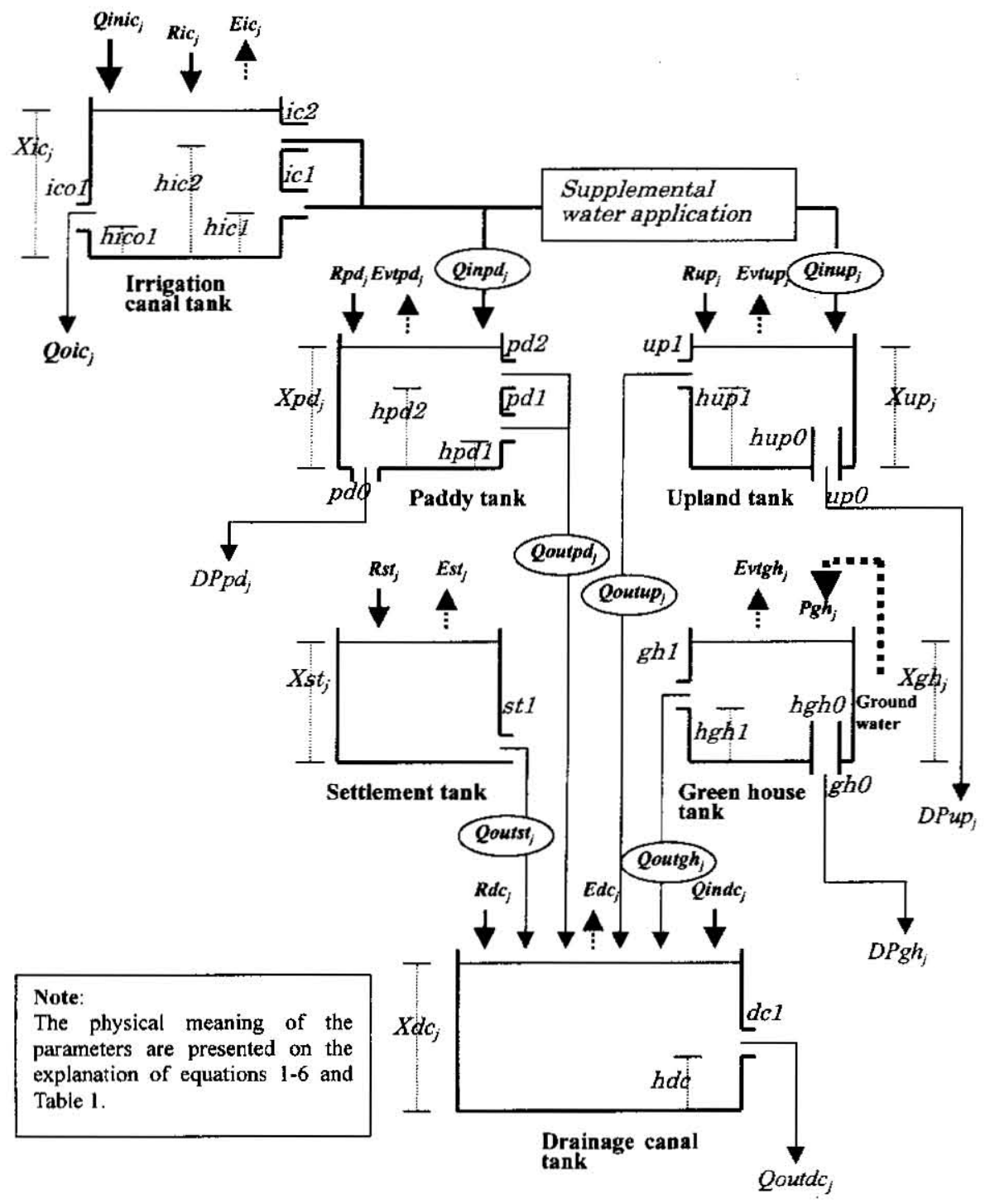

Fig. 3. The Complex Tank Model for Simulating Water Cyclic in the System. 
Table 2. Obtained coefficients of the tank model.

\begin{tabular}{|c|c|c|c|c|c|c|}
\hline Sub tank & $\begin{array}{c}\text { Irrigation } \\
\text { canal tank }\end{array}$ & $\begin{array}{l}\text { Paddy } \\
\text { Tank }\end{array}$ & $\begin{array}{l}\text { Upland } \\
\text { tank }\end{array}$ & $\begin{array}{c}\text { Greenhouse } \\
\text { tank }\end{array}$ & $\begin{array}{c}\text { Settlement } \\
\text { tark }\end{array}$ & $\begin{array}{c}\text { Drainage } \\
\text { tank }\end{array}$ \\
\hline $\begin{array}{c}\text { the size of } \\
\text { outlet }\end{array}$ & $\begin{array}{l}i c 1=0.1224, \\
i c 2=0.2247, \\
i c 01=0.3012\end{array}$ & $\begin{array}{l}p d 1=0.1001, \\
p d 2=0.4711, \\
p d 0=0.3244\end{array}$ & $\begin{array}{l}u p 0=0.3879 \\
u p 1=0.4274\end{array}$ & $\begin{array}{l}g h 0=0.2879 \\
g h 1=0.4023\end{array}$ & $s t 1=0.5442$ & $d c 1=0.7024$ \\
\hline $\begin{array}{l}\text { the height of } \\
\text { outlet (mm) }\end{array}$ & $\begin{array}{l}\text { hic } 1=3, \\
\text { hic } 2=50, \\
\text { hico } 1=1\end{array}$ & $\begin{array}{l}h p d 1=10 \\
h p d 2=50\end{array}$ & $\begin{array}{l}\text { hup } 0=27 \\
\text { hup } 1=30\end{array}$ & $h g h 0=28$ & $s t 1=0.5442$ & $h d c=3$ \\
\hline
\end{tabular}

The performance of water operation in the system is extremely dependent upon the accuracy of the estimated runoff due to the limitation of observed discharge data. Therefore, the tank model was run in two steps. First is to run the sub irrigation canal tank. In this case, the target is to find out the reasonable water inflow into paddy fields and upland fields. Furthermore, the parameters of the model that are constant coefficients of height of outlet, the outlet and initial water depth for irrigation canal tank are obtained. The simulated and observed outflow discharges from irrigation canal were used for examining accuracy of the model. The optimal combination of coefficients was obtained from minimizing the objective function $\boldsymbol{J}$ as shown in equation (7). Second is to run all of sub tank models, the simulated and observed outflow discharges from drainage canal were used for examining accuracy of the model. Furthermore, equation (7) was also used for obtaining the optimal combination of coefficients. The obtained coefficients of the tank model are presented in Table 2.

$$
J=\sum_{i=1}^{n}\left(Q O_{2}-Q c_{2}\right)^{2} / Q O_{i}
$$

Where $n$ is number of data, $Q O_{i}$ and $Q c_{i}$ are observed discharge and simulated discharge, respectively.

\section{RESULTS AND DISCUSSION}

\section{Performance of simulated discharge}

Using the optimized values of the Tank Model parameters, simulation of the daily discharge can be run. Figure 4 shows the performance of simulated discharge from drainage canal. Results shows that the optimized parameters produce the simulated discharges are close to the observed ones.

Fig. 5 shows the water discharge components due to the type of land use in the system. Results show that the discharge from paddy fields is the dominant part. The discharge from upland fields is the second ones. And the discharge from settlement areas is the third ones, which only appear when the rainfall happens in the system. The discharge from greenhouses is the minor part compared to those from the other fields.

Fig. 6 displays the water discharge component from paddy fields for 4 years analysis. It can be seen that percolation is the dominant discharge, which is around $32.68 \mathrm{~mm} /$ day due to the high porosity of soil. The second one is the surface discharge around 

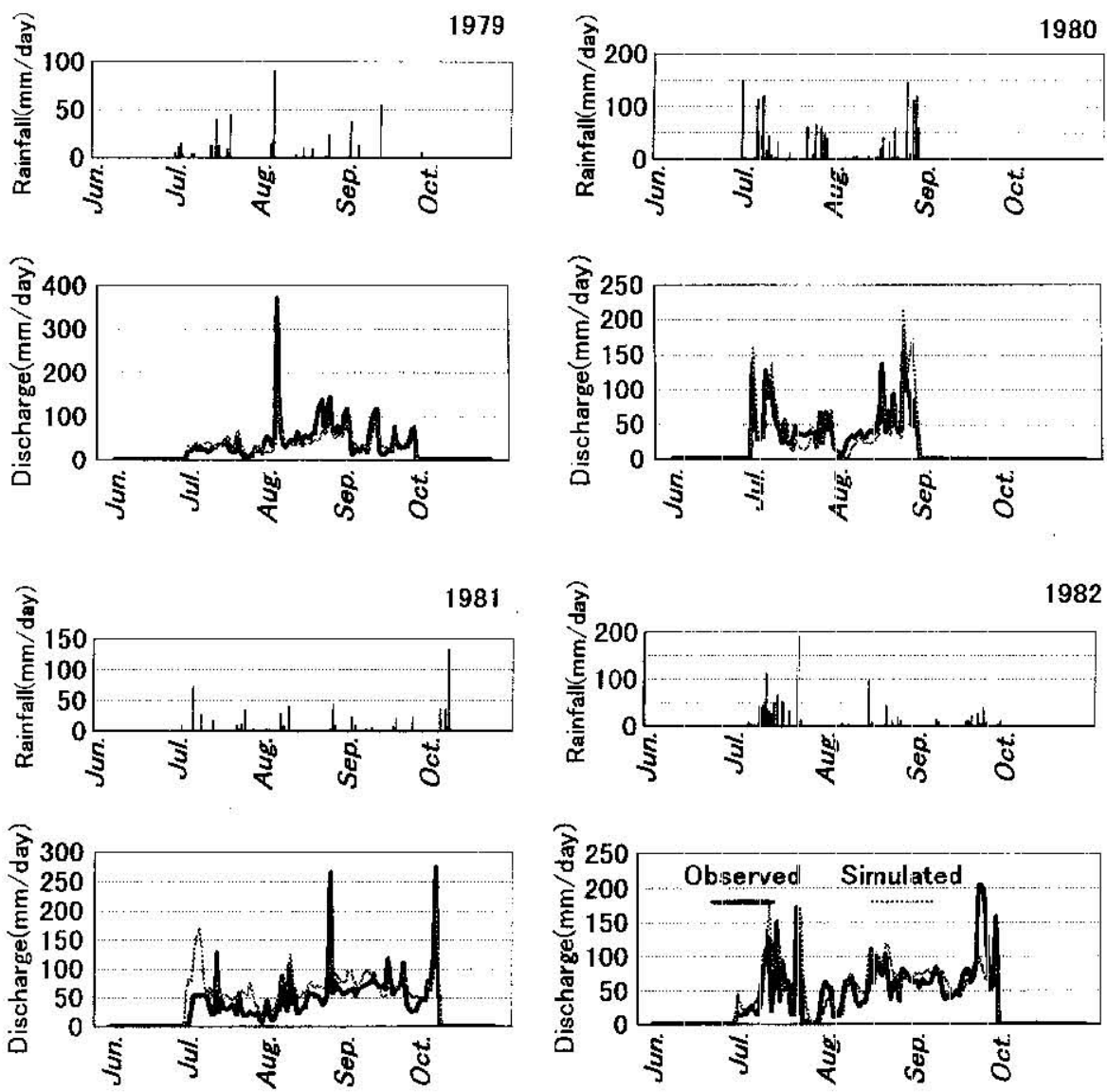

Fig. 4. Observed and simulated discharge from drainage canal (14.76 ha). Note: From Jul. to. Oct. (1979, 1981, 1982), Jul. to Sep. (1980).

This condition is also same for the other graphs.

$24.68 \mathrm{~mm} /$ day. The seepage is the minor part compared to other discharge around $9.14 \mathrm{~mm} /$ day.

\section{Net Water Requirement Analysis}

This is the net quantity of water demanded in paddy plot and expressed in the following equation.

$$
\begin{aligned}
& N W R_{j}=D P p d_{i}+Q_{\text {outpd }}+E v t p d_{j}-R p d_{j} \\
& \text { Qoutpd }_{j}=Q S r p d_{j}+Q S p p d_{j}
\end{aligned}
$$

Where: $N W R$, is the net quantity water requirement at period $j$; $Q S r p d$, and $Q S p p d_{f}$ are the surface discharge and the seepage from paddy fields, respectively. The meaning of other symbol in equation (8) is same as mentioned in equation (2). 

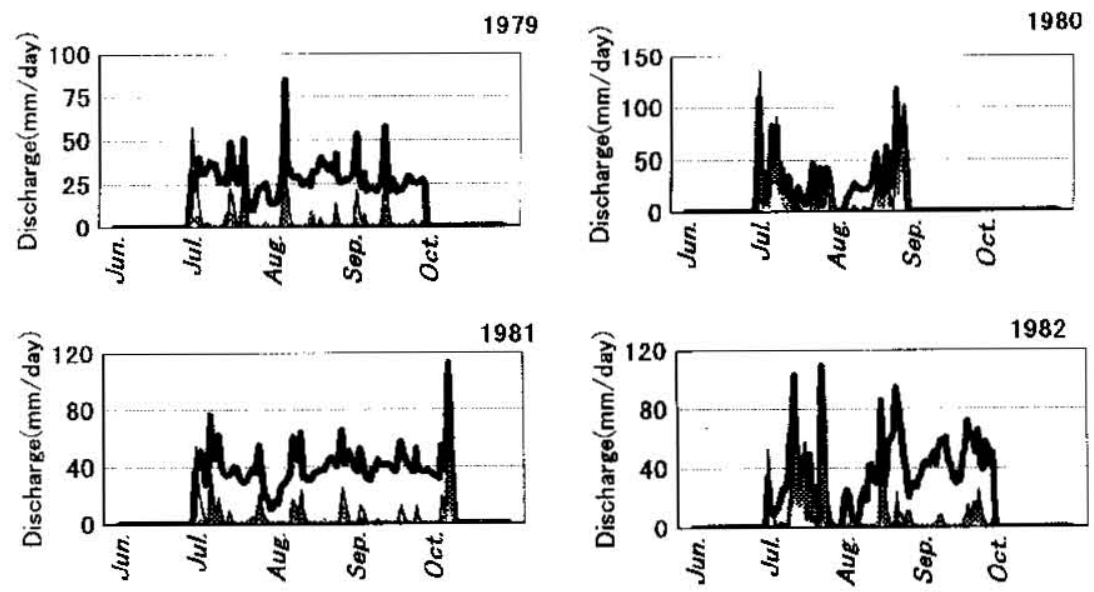

Paddy field Upland Settlement Green house

Fig. 5. Water discharge components due to land use system (14.76 ha)
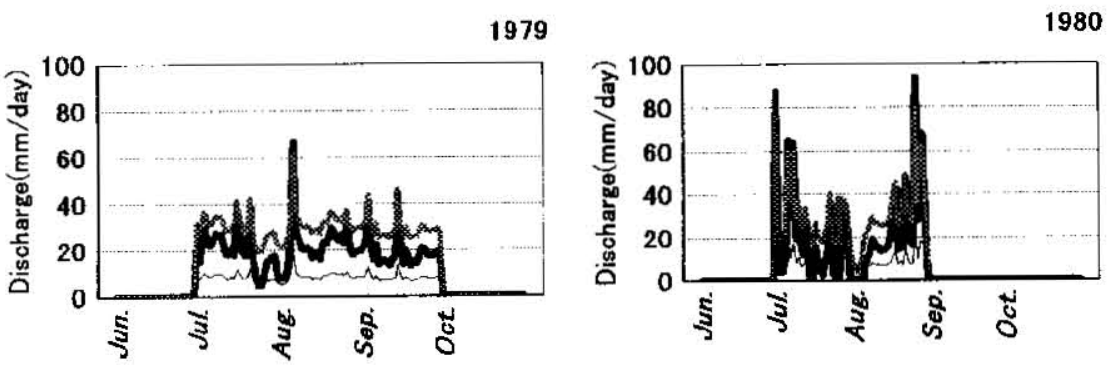

1981
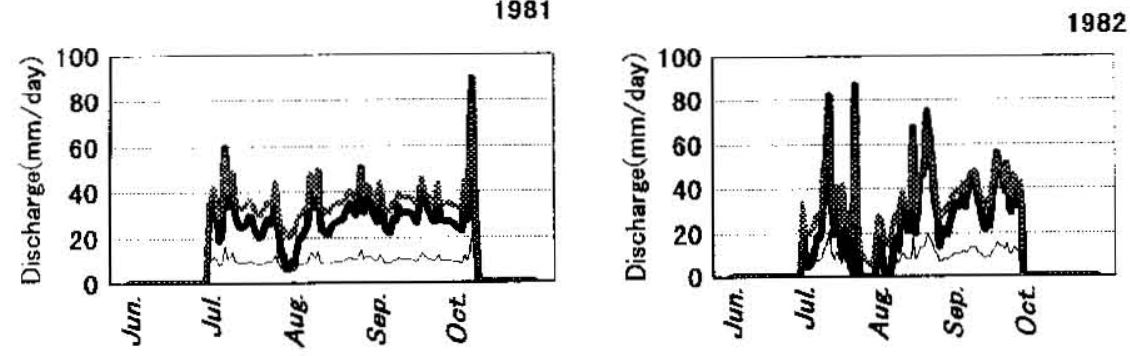

Surface

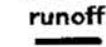

Percolation

Seepage

Fig. 6. Water discharge components from paddy ficlds ( $14.76 \mathrm{ha}$ ). 


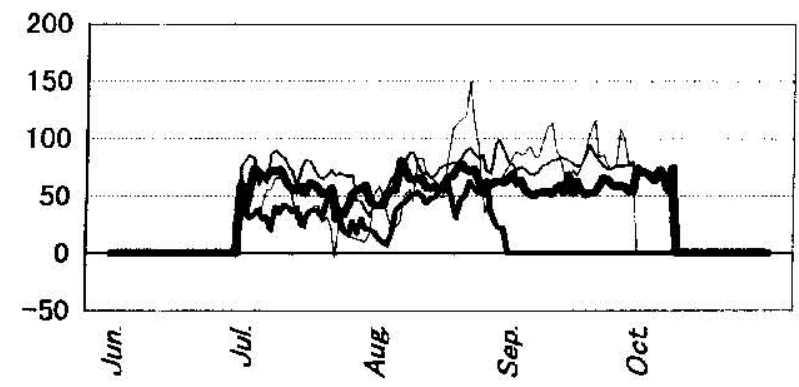

Fig. 7. Simulated net water requirement of paddy fields (14.76 ha).

Figure 7 presents the net water requirement for 4 years analysis. The graph shows that the net water requirements have a same pattern, except for 1980 due to the lack of amount data. The averages of the net water requirement for 1979, 1980, 1981 and 1982 were around $60.20 \mathrm{~mm} /$ day, $37.14 \mathrm{~mm} /$ day, $74.33 \mathrm{~mm} /$ day and $63.90 \mathrm{~mm} /$ day, respectively. Furthermore, the average data of 1980 was neglected because this value did not show a reasonable result. From the data of 1979,1981 and 1982, the average of net water requirement was around $66.14 \mathrm{~mm}$ day. In this area, the deep percolation and the surface discharge were the dominant components of net water requirement as shown in Fig. 6 . The performance of water management, especially for field management that is reflected by the amount of the surface discharge, has to be concerned for increasing the efficiency of water management itself. Maruyama et al. (1995) reported that irrigation water for field management conducted for various proposes such as drainagc of ponded water, mid summer drainage, fertilizer or chemical solvent and water management labor. The amount of irrigation water for field management relates to the knowledge of farmer in operating the irrigation water. So, the irrigation for ficld management can be minimizes as long as the farmer operates the irrigation water in a strict condition. Furthermore, the amount of deep percolation seemed to be constant because the deep percolation was affected by the soll porosity. Nlthough Koga (1992) reported that soil-dressing method could be implemented for controlling percolation, the farmers did not adopt the method to their paddy fields.

\section{Gross Water Requirement Analysis}

The study area was around 695 ha consisted of paddy fields ( $340 \mathrm{ha})$, upland fields (244 ha), greenhouses ( $72 \mathrm{ha}$ ) and settlement areas ( $39 \mathrm{ha})$. The plot model of paddy fields that was discussed above included inside of this area. The intake water from Yamada weir of 1998 named observed gross water requirement was taken as the input parameter to the area. The target of this work was to predict the gross water requirement using the acceptable tank model and to verify again the accuracy of the tank model. Furthermore, the simulated gross water requirement shows the water quantity that should be diverted at diversion point in each irrigation scheme is expressed in equation (10). 


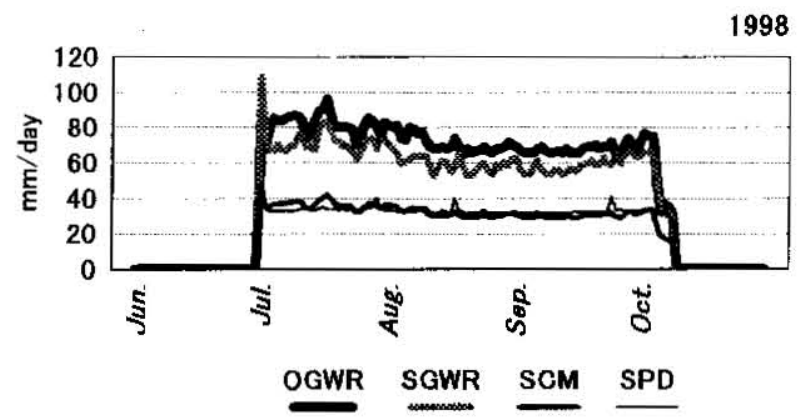

Fig. 8. Observed gross water requirement (OGWR), simulated gross water requirement (SGWR), simulated casal management. (SCM) and simulated ponding depth (SPI))(695 ha).

$$
G W R_{j}=N W R_{j}+C M_{j}-R d p_{j}-R E_{j}
$$

Where: $\mathrm{GWR}_{j}$ is gross water requirement at period $j$; $C M_{j}$ is the amount of water that is lost by the management canal system; $R d p_{l}$ is the rainfall in diversion point; $R E_{j}$ is amount of reuse water.

Fig. 8 displays the observed gross water requirement (OGWR), the simulated gross water requirement (SGWR), the simulated canal management (SCM) and the simulated ponding depth (SPD). The simulated gross water requirement and simulated canal management were obtained from the application of the acceptable tank model. Fig. 8 presents that the average of the observed gross water requirement $(71.95 \mathrm{~mm} /$ day $)$ was slightly higher than the average of the simulated gross water requirement $(62.37 \mathrm{~mm} / \mathrm{day})$. It depicts that the acceptable tank model can be used for predicting the gross water requirement in the area. Furthermore, the average of simulated ponding depth $(33.64 \mathrm{~mm} /$ day $)$ and the average of canal management $(32.45 \mathrm{~mm} /$ day $)$ were also reasonable as shown in Fig. 8.

In this area, the Land Improvement District (LID), which is the water user association, decides the gross water requirement. The gross water requirement usually ranged of $5-6 \mathrm{~m} / \mathrm{s}$ (ranged of $62.16-74.59 \mathrm{~mm} /$ day). It means that the simulated gross water requirement $(62.37 \mathrm{~mm} /$ day $)$ was more efficient. The simulated ponding depth also supported this argument. In the other word, the LID can use the simulated gross water requirement as reference for deciding the gross water requirement in this area.

\section{Numerical Treatment of Gross Water Requirement}

Another method in evaluating the gross water requirement is to analyze the reasonability of gross water requirement itself. In this case, numerical treatment of gross water requirement was considered as the quantity that should be diverted in diversion point. The numerical treatment of gross water requirement was consisted of $1 \mathrm{~m}^{3} / \mathrm{s}$, $3 \mathrm{~m}^{3} / \mathrm{s}, 5 \mathrm{~m}^{3} / \mathrm{s}, 7 \mathrm{~m}^{3} / \mathrm{s}$ and $9 \mathrm{~m}^{3} / \mathrm{s}$. The simulated ponding depth of paddy fields was taken as 
standard for evaluating the reasonability of the gross water requirement. Usually, the actual ponding depth ranges of $30-50 \mathrm{~mm} /$ day. Furthermore, the increasing quantity of the numerical treatment of gross water requirement tends to produce the increasing the irrigation water for the canal management. Therefore, the irrigation water for the canal management has also to be considered for finding the reasonable water requirement.

Fig. 9 depicts the simulated ponding depth and canal management due to numerical treatment of gross water requirement. Fig. 9 shows that the input quantity of gross water requirement below $5 \mathrm{~m}^{3 /} / \mathrm{s}$ can not yield a reasonable ponding depth (less than $30 \mathrm{~mm} /$ day). In this situation, the growth of paddy crops will be disturbed due to the lack of available water. Furthermore, the increasing quantity of gross water requirement from
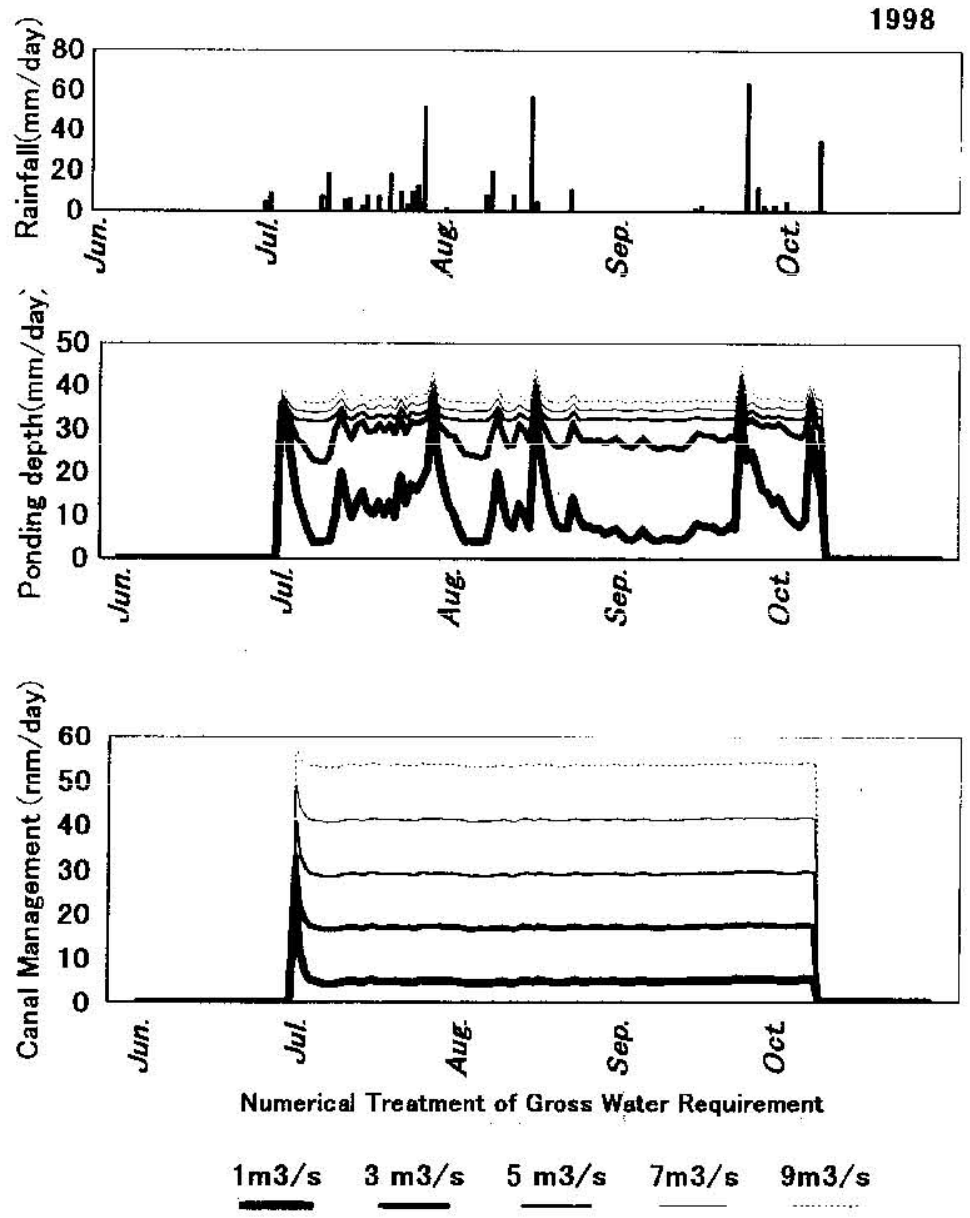

Fig. 9. Simulated ponding depth and canal management due to numerical treatment of gross water requirement (695 ha). 
$7 \mathrm{~m} / \mathrm{s}$ up to $9 \mathrm{~m}^{3} / \mathrm{s}$ will also produce the increasing irrigation water for canal management from $41.65 \mathrm{~mm} /$ day up to $53 \mathrm{~mm} /$ day. In the other word, the water loss due to the canal management tended to increase too. It means that the application of the gross water requirement that was more than $5 \mathrm{~m}^{3} / \mathrm{s}$ categorized inefficient. This phenomenon depicted that the gross water requirement of $5 \mathrm{~m}^{3} / \mathrm{s}$ was reasonable to be applied for paddy field system in this area, which was provide the ponding depth of $33.16 \mathrm{~mm} /$ day.

\section{CONCLUSIONS}

The tank model can be used for clarifying the water requirement phenomena in paddy field system in this area. Using the acceptable tank model, the daily discharge can be conducted. Results based on historical data shows that the paddy fields yielded the dominant discharge compared to the other land use type. The quantity of net water requirement was around $66.14 \mathrm{~mm} /$ day that was obtained using the acceptable of the tank model in this area. The deep percolation and the surface runoff from the paddy fields were the dominant component of the net water requirement, which were around $32.68 \mathrm{~mm} /$ day and $24.68 \mathrm{~mm} /$ day, respectively.

The acceptable of the tank model was applied for predicting the gross water requirement. Results showed that the observed gross water of 1998 was slightly higher than the simulated gross water requirement, which were around $71.95 \mathrm{~mm} /$ day and $62.37 \mathrm{~mm} /$ day, respectively. The simulated gross water requirement can be taken as reference for deciding the gross water requirement in this area because it is more efficient. The simulated ponding depth also supported this result, which was around $33.64 \mathrm{~mm} /$ day.

The results of numerical trcatment of gross water requirement showed that the application of $5 \mathrm{~m}^{3} / \mathrm{s}$ was reasonable compared to other treatment. The application of gross water requirement less than $5 \mathrm{~m}^{3} / \mathrm{s}$ will disturb the growth of paddy crops due the shortage water in this condition. On the contrary, the application of gross water requirement more than $5 \mathrm{~m}^{3} / \mathrm{s}$ will produce the increasing of canal management (water loss) from the system, which mean the performance of water management categorized inefficient.

\section{REFERENCES}

Basri, H., T. Fukuda and M. Kuroda 1998 Water Balance Evaluation and Water QualityAnalysis of Paddy Ficld Irrigation System in Low Lying Area. J. Fac. Agr., Kyushu Univ., 43(1-2), 227-237.

Koga, K. 1992 Introduction to P'addy Fiekd Engineering. Asian Institute of Technology,Bangkok: 47-61.

Kuroda, M. 1985. Report of Surveying Irrigation and Drainage Water in Asakura Area,Fukuoka Prefecture, Japan. Agricultural Engineering Rescarch Report: 26-59 (in Japanese).

Maruyama et al. 1995 Irrigation and Drainage. Yakendo Ltd, Tokyo: 71-78 (in Japanese).

Mizutani, M. 1991. On Farm Water Management Technology. Training on Advanced Agriculture Engineering, IPB, Bogor, Indontesia: 5-13.

Sugawara, M., I. Watanabe, E. Ozaki and Y. Katsuyama 1984 Tank Model with SnowComponent. National Research Center for Disaster Prevention, Japan. 163-194.

Sugawara, M., I. Watanabe, E. Ozaki and Y. Katsuyama 1986 Tank Model Programs forPersonal Computer and the Way to Use. National Rescarch Center for Disaster Prevention, Japan. 5-56 (in Japanese). 